\title{
Sensing performances of Semiconducting Carbon Nanomaterials based Gas Sensors Operating at Room Temperature
}

\author{
Sun-Woo Choi ${ }^{\dagger}$ \\ Department of Materials Science and Engineering, Kangwon National University, \\ Chuncheon 24341, Korea

\section{반도체 탄소 나노재료 기반 상온 동작용 가스센서} \\ 최선우 \\ 강원대학교 신소재공학과
}

(Received March 8, 2019; Accepted March 22, 2019)

\begin{abstract}
s
Semiconducting carbon-based nanomaterials including single-walled carbon nanotubes(SWCNTs), multi-walled CNT(MWCNTs), graphene(GR), graphene oxide(GO), and reduced graphene oxide(RGO), are very promising sensing materials due to their large surface area, high conductivity, and ability to operate at room temperature. Despite of these advantages, the semiconducting carbon-based nanomaterials intrinsically possess crucial disadvantages compared with semiconducting metal oxide nanomaterials, such as relatively low gas response, irreversible recovery, and poor selectivity. Therefore, in this paper, we introduce a variety of strategies to overcome these disadvantages and investigate principle parameters to improve gas sensing performances.
\end{abstract}

Keywords: Room temperature, Semiconducting carbon-based nanomaterials, Sensing performance, Gas sensors

\section{1. 서론}

1962년 Seiyama 교수1)에 의해 벌크(bulk) 형태의 산 화물 반도체 기반 가스 센서가 최초로 제안된 이래 후막 (thick film) 및 박막(thin film) 형태의 산화물 가스 센 서 연구개발을 거쳐 최근에는 나노섬유(nanofiber), 나노선(nanowire), 나노막대(nanorod), 나노튜브 (nanotube) 등과 같은 저차원(low-dimensional structure) 나노재료를 활용한 산화물 가스센서 개발이 활발히 진행되고 있다. 벌크 및 박막 재료와는 다르게 독 특한 물리적, 화학적 성질을 가지고 있는 저차원 구조의 나노재료는 구조, 형상, 크기 등을 제어함으로써 감응 특 성을 획기적으로 향상시킬 수 있는 장점이 있다. 특히, 나 
노재료가 가지는 부피 대비 높은 비표면적비의 장점은 감 응 재료의 표면과 검지 목표 화학물질(주로 화학가스 분 자) 사이의 반응성 여부가 중요한 저항변화식 (chemiresistive) 가스 센서 분야에서는 중요한 요소로 인식되고 있다.2) 저항변화식 가스 센서는 감응 재료 표면 에 흡착되어 이온화된 산소와 검지 가스분자의 반응이 필 수적 요소이므로 감응 재료의 저항변화를 극대화하기 위 해서는 감응 재료의 표면적을 중가시켜 검지 가스분자와 의 표면반응을 향상시키는 방안이 필요하다. 이러한 전략 으로 독특한 구조의 감응 재료 설계, 표면 기능화(surface engineering) 및 이종 물질간의 복합체(composite) 합 성 등 나노재료의 구조를 활용한 다양한 연구 사례가 보 고되고 있다 ${ }^{3-5)}$.

반도체 기반 감응 재료의 가스 감응 메커니즘은 잘 알 려진 바와 같이 매우 단순하다. $\mathrm{n}$-형 반도체 감응 재료 의 산화성 및 환원성 가스들에 대한 감응 원리를 예로 들 면 다음과 같다. 일반적으로, 공기 중의 산소 분자는 비 교적 고온 $\left(100^{\circ} \mathrm{C}\right.$ 이상 $)$ 의 온도에서 감응 재료의 표면에 흡착을 하고, 흡착된 산소 분자는 감응 재료 표면의 전자 를 빼앗아 음전하 상태의 산소 음이온으로 된다. 따라서 감응 재료의 표면에는 전자가 부족한 상태인 전자공핍층 (electron depletion layer)이 형성되고 감응 재료 간의 계면에는 전위장벽(potential barrier)이 형성되어 감응 재료의 전체 저항은 매우 높은 상태가 된다. 이 때, 감응 재료 표면에 산화성 가스가 흡착되면 감응 재료 내부의 전자가 산화성 가스 분자로 이동하게 되어 전자공핍층은 더욱 확장되므로, 감응 재료의 전체 저항이 증가하게 된 다. 이와 반대로, 환원성 가스가 감응 재료 표면에 노출 되면 기 흡착된 산소 이온과 반응하여 휘발성분자로 산화 하여 날아가고 감응 재료로부터 획득했던 산소 이온의 전 자는 다시 감응 재료 내의 전도대로 돌아가게 된다. 따라 서 감응 재료의 전자공핍층의 두께는 축소되고 전체 저항 은 감소하게 된다.

이러한 저차원 산화물 반도체 나노재료 기반의 가스 센 서는 생산 단가가 저렴하여 대량 생산에 유리할 뿐만 아 니라, 소형화/집적화가 용이하여 전기전자기기와의 결합 이 가능한 매우 실용적인 기술로 인식되어 현재까지 활발
한 연구가 진행 중에 있다. 그러나 위와 같은 장점에도 불 구하고 상용 센서로의 적용을 위해 많은 개선점이 요구된 다. 특히, 미량의 유해화학가스(독성, 폭발성 및 휘발성 가스)를 선제적으로 검지할 수 있도록 고감도를 유지하면 서 양호한 가스 선택성을 가지고, 저전력 구동이 가능하 도록 동작 온도 $\left(100{ }^{\circ} \mathrm{C}\right.$ 이하)를 낮출 수 있는 감응 재료 개 발이 필요하다. 본 소고에서는 상온 동작이 가능한 다양 한 형태의 탄소 기반 나노재료를 가스 센서 분야에 적용 한 사례에 대해 비교 - 분석하고, 상온에서의 탄소 나노재 료 기반 반도체 가스 센서의 성능 향상을 위한 다양한 전 략들과 감응 특성 및 감응 메커니즘에 대해 고찰하고자 한다.

\section{2. 본론}

앞서 서술한 바와 같이 상온에서 피검 가스에 대한 감 응도와 선택성을 향상시키기 위해 저차원 나노구조물의 재료 선택에서부터 저차원 나노재료의 구조 설계 등 다양 한 전략이 연구되었다. 그 중에서도 2000년 이후 활발히 연구되고 있는 탄소 나노재료(탄소나노튜브, 그래핀 등) 기반 감응 소재의 상온 감응 특성 향상 방안과 그 결과에 대해 살펴보고자 한다.

\section{1 탄소 나노재료 기반 상온 동작 가스센서}

1 차원의 나노구조물을 활용한 가스센서 연구가 활성화 되던 2000 년에 비교적 고온 $\left(300^{\circ} \mathrm{C}\right.$ 이상 $)$ 에서 동작이 가 능했던 산화물 기반의 가스센서와 달리 탄소나노튜브 (CNT)를 이용한 가스센서는 상온에서 동작이 가능하였 다. Kong 등6)은 개별의 단일벽 탄소나노튜브(SWCNT) 를 활용한 전계효과트랜지스터(FET, Field Effect Transistor)형 가스센서를 제작하였고, 대표적인 산화성 가스로는 $\mathrm{NO}_{2}$, 환원성 가스로는 $\mathrm{NH}_{3}$ 가스를 선정하여 감응 특성을 평가하였다. $\mathrm{FET}$ 형 센서 소자에 활용된 SWCNT는 산화성 가스인 $\mathrm{NO}_{2}$ 분자에 대해서는 초기 저 항값이 감소하고, 환원성 가스인 $\mathrm{NH}_{3}$ 분자에는 저항값이 증가하는 $\mathrm{p}$-형 반도체 거동을 보였다. 이 논문에서 소개 한 SWCNT 기반 FET형 가스센서는 게이트 전압 $\left(\mathrm{V}_{\mathrm{g}}\right)$ 크 
기에 따른 소스(source)-드레인(drain) 간의 전류 변화 로 가스를 검지하는 방식으로 기존의 저항의 변화를 신호 로 이용하는 산화물 반도체형 가스센서 소자와는 구동 방 식이 다르지만, 상온에서의 높은 가스 감도를 실현하였다 는 관점에서 상온 동작형 감응 재료로써 SWCNT를 응용 할 수 있는 새로운 가능성을 제시하였다.

해당 연구결과 이후 수 많은 연구자들에 의해 SWCNT 를 포함한 탄소소재를 이용한 가스센서 연구가 시행되었 다 ${ }^{7-9)}$. 산화물 반도체형 가스센서의 동작 온도가 $300^{\circ} \mathrm{C}$ 이상인 경우와 비교해 Table 1에 나타난 바와 같이 탄소 소재를 이용한 가스센서의 경우 대부분의 감응 온도가 상 온에서 $100^{\circ} \mathrm{C}$ 범위에서 구동되는 것을 알 수 있다. 이와 같은 센서의 낮은 동작 온도는 센서 구동을 위한 전력이 적게 소모되어 여러 전기전자기기와의 결합에 유리한 측 면이 있지만, 감응도 저하, 낮은 선택성 그리고 느린 반 응 속도 및 불완전한 회복 등과 같은 점은 개선되어야 문 제점으로 남았다.

\section{2 금속 입자-탄소소재 복합체 기반 상온 동작 가스센서}

탄소 나노재료 기반 가스센서에서 감응 재료의 향상된
감응도를 확보하기 위한 방안으로 가장 흔히 사용되는 방 법이 나노 크기의 금속 입자를 탄소소재 표면에 기능화 하는 것이다. 최근까지 탄소소재 표면에 촉매 물질로써 다양한 금속 입자를 기능화하여 특정 가스에 대해 고감 도/고선택성을 보이는 감응 소재를 연구한 사례들이 다 수 보고되고 있다.

$\mathrm{CO}$ 가스 감응 특성을 향상시키기 위해 $\mathrm{Al}$ 금속 촉매가 첨가된 그래핀(GR, Graphene) 기반 가스 센서에 대한 연구결과가 보고된 바 있다. Jiang 등28)은 밀도함수이론 (DEF, Density Functional Theory)을 이용하여 $\mathrm{CO}$ 분 자의 흡착을 향상시킬 수 있는 원리로 $\mathrm{Al}$ 입자를 그래핀 표면에 첨가하는 방안을 이론적으로 도출하였다. 이 방법 을 통해 제조된 $\mathrm{Al}$ 이 첨가된 $\mathrm{GR}$ 센서는 획기적으로 향상 된 $\mathrm{CO}$ 가스 감응 특성을 보였다. 위 연구는 GR 표면에 금속 촉매를 기능화함으로써 금속 촉매와 피검 가스 분자 사이에 강한 결합을 형성하여 피검 가스에 대한 감응 특 성을 향상시킬 수 있다는 점과 금속 촉매의 종류에 따라 피검 가스의 종류도 선택적으로 선정할 수 있는 가능성을 보였다는 점에서 큰 의의를 가진다.

Huang 등 29$)$ 은 $\mathrm{NO}_{2}$ 가스 감응 특성 향상을 위해 환원 된 그래핀 산화물(RGO, Reduced Graphene Oxide)을

Table 1. 탄소소재(SWCNT, MWCNT, GR, GO, RGO) 기반 반도체 가스센서

\begin{tabular}{|c|c|c|c|c|c|}
\hline Materials & Gas Species & Concentration & Operating Temperature & Response & Ref. \\
\hline SWCNT network & $\mathrm{NO}_{2}$ & $500 \mathrm{ppm}$ & $\mathrm{RT}$ & $20 \%$ & 10 \\
\hline SWCNT array & $\mathrm{NH}_{3}$ & $200 \mathrm{ppm}$ & $\mathrm{RT}$ & $3.5 \%$ & 11 \\
\hline SWCTN aligned array & $\mathrm{NH}_{3}$ & 10 ppm & $\mathrm{RT}$ & $150 \%$ & 12 \\
\hline MWCNT bucky paper & Acetone & $2.34 \mathrm{vol} \%$ & $\mathrm{RT}$ & $6 \%$ & 13 \\
\hline GR & $\mathrm{CO}_{2}$ & 100 ppm & RT & $25 \%$ & 14 \\
\hline RGO & $\mathrm{NO}_{2}$ & $100 \mathrm{ppm}$ & $\mathrm{RT}$ & $1.5 \%$ & 15 \\
\hline $\mathrm{RGO}$ & $\mathrm{H}_{2}$ & $160 \mathrm{ppm}$ & $\mathrm{RT}$ & $4.5 \%$ & 16 \\
\hline $\mathrm{GO}$ & $\mathrm{SO}_{2}$ & $50 \mathrm{ppm}$ & $\mathrm{RT}$ & $47 \%$ & 17 \\
\hline GR & $\mathrm{NO}_{2}$ & $25 \mathrm{ppm}$ & $\mathrm{RT}$ & $38.9 \%$ & 18 \\
\hline Pd-SWCNT & $\mathrm{H}_{2}$ & $10,000 \mathrm{ppm}$ & $\mathrm{RT}$ & $25 \%$ & 19 \\
\hline $\mathrm{Au}-\mathrm{SWCNT}$ & $\mathrm{NH}_{3}$ & $6 \mathrm{ppm}$ & $\mathrm{RT}$ & $0.12 \%$ & 20 \\
\hline $\mathrm{SnO}_{2}-\mathrm{SWCNT}$ & $\mathrm{H}_{2}$ & $1 \mathrm{vol} \%$ & $\mathrm{RT}$ & $4 \%$ & 21 \\
\hline $\mathrm{SnO}_{2}-\mathrm{MWCNT}$ & $\mathrm{NO}_{2}$ & $100 \mathrm{ppb}$ & $50^{\circ} \mathrm{C}$ & $5500\left[\left(\mathrm{R}_{\mathrm{g}}-\mathrm{R}_{\mathrm{a}}\right) / \mathrm{R}_{\mathrm{a}}\right]$ & 22 \\
\hline ZnO-MWCNT & Ethanol & $50 \mathrm{ppm}$ & $\mathrm{RT}$ & $4.5 \%$ & 23 \\
\hline $\mathrm{VO}_{2}-\mathrm{MWCNT}$ & $\mathrm{NH}_{3}$ & $45 \mathrm{ppm}$ & $\mathrm{RT}$ & $10 \%$ & 24 \\
\hline $\mathrm{Pd}-\mathrm{GR}$ & $\mathrm{H}_{2}$ & $2000 \mathrm{ppm}$ & $100^{\circ} \mathrm{C}$ & $110 \%$ & 25 \\
\hline $\mathrm{Pd}-\mathrm{Pt}-\mathrm{GR}$ & $\mathrm{H}_{2}$ & 2 vol\% in $\mathrm{Ar}$ & RT & $4 \%$ & 26 \\
\hline $\mathrm{WO}_{3}-\mathrm{Pd}-\mathrm{RGO}$ & $\mathrm{H}_{2}$ & $20 \mathrm{ppm}$ & $100^{\circ} \mathrm{C}$ & $150 \%$ & 27 \\
\hline
\end{tabular}



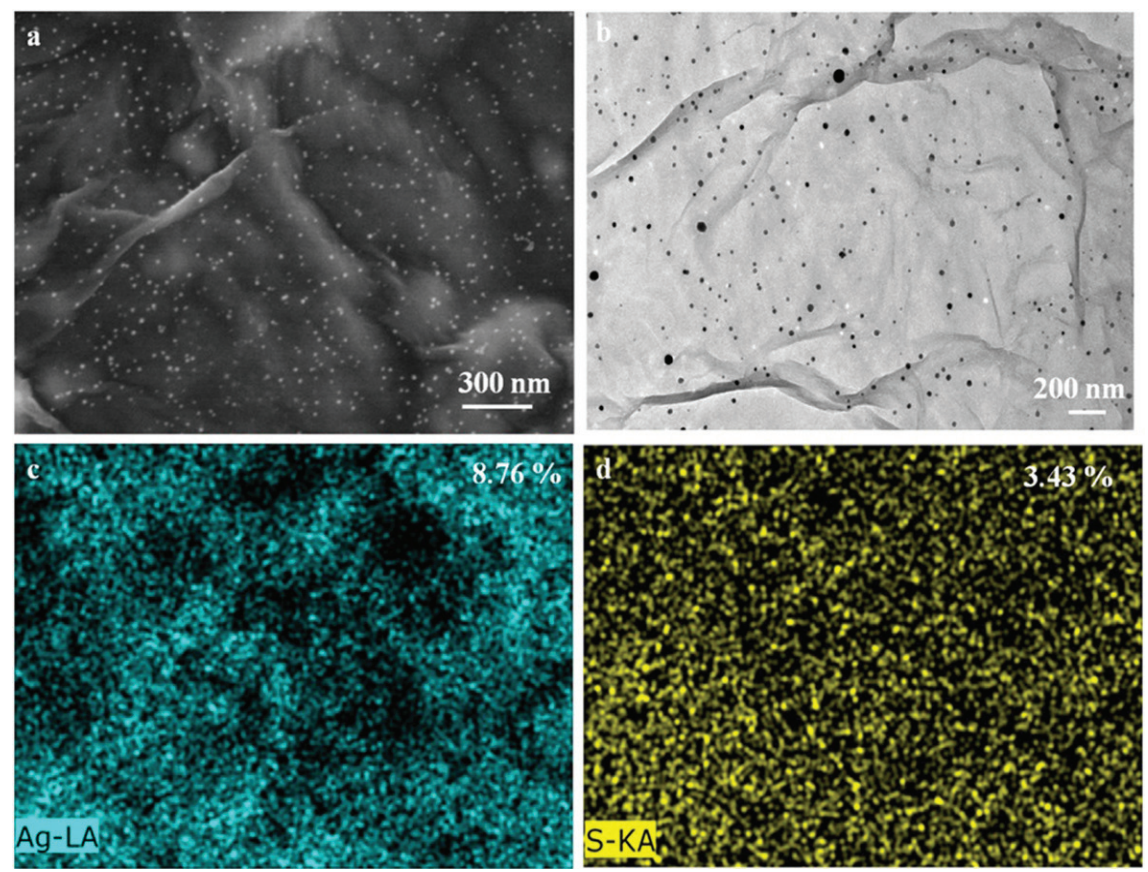

Fig. 1. 술폰화(sulfonated) 처리한 RGO 표면에 $\mathrm{Ag}$ 입자 기능화된 감응 재료 ${ }^{29)}$

술폰화(sulfonated) 처리한 후 $\mathrm{Ag}$ 나노 입자를 기능화한 감응 재료를 제작하였다(Fig. 1). 화학적 처리를 통해 제 조한 RGO 시트를 다시 술폰화 처리하여 황산 작용기 $\left(-\mathrm{SO}_{3} \mathrm{H}\right)$ 를 $\mathrm{RGO}$ 표면에 기능화한 후, 이를 $\mathrm{AgNO}_{3}$ 용액 에 $50^{\circ} \mathrm{C}$ 에서 2 시간 동안 환원하여 최종적으로 $10-20$ $\mathrm{nm}$ 범위의 크기를 가지는 $\mathrm{Ag}$ 나노 입자와 황산 작용기 를 동시에 $\mathrm{RGO}$ 표면에 기능화시키는 전략으로 $\mathrm{NO}_{2}$ 감 응 효과를 향상시키고자 하였다. 이 방법을 통해 $\mathrm{Ag}$ 촉매 입자가 응집없이 고르게 술폰화 처리된 $\mathrm{RGO}$ 표면에 고 착되어 기능화됨으로써 $50 \mathrm{ppm} \mathrm{NO}$ 가스에 대해 상온 에서 $74.6 \%$ 의 감도를 보였고, 응답 시간과 회복 시간은 각각 12 초와 20 초의 매우 빠른 속도를 나타내었다. 또한 유연 가스센서 소자 적용을 위해 1000 번 이상의 굽힘 시 험에서도 일정한 감응 특성을 유지할 정도의 안정성이 확 보되었다. 위 연구는 금속 촉매와 황산 작용기를 동시에 탄소 나노재료에 기능화함으로써 감응 재료의 감도를 향 상시키는 새로운 방법을 제안하였을 뿐만 아니라 유연 가 스센서 소자 적용이 가능한 안정성이 확보된 감응 재료임 을 보여주는 결과이다.
Byun 등 ${ }^{30}$ 은 $\mathrm{DMF}\left(1,2\right.$-dichlorobenzene, $\mathrm{C}_{6} \mathrm{H}_{4} \mathrm{Cl}_{2}$ ) 용매에 상용 SWCNT 필름을 고르게 분산시킨 후, 스프 레이 기법을 이용하여 네트워킹 구조의 SWCNTs 기반의 감응 재료를 제조하였다(Fig. 2). 제조된 네트워킹 구조 의 SWCNT 표면에 Pt 촉매 입자를 기능화하기 위해 UV 조사를 이용한 광 환원법을 사용하였다. UV 조사와 동시 에 용매에 포함된 Pt 이온이 SWCNT 표면에서 환원이 시 작되어 금속 촉매 입자로 성장을 하기 때문에 금속 촉매 의 응집 현상을 최소화하여 촉매의 효과를 극대화 할 수 있었다. 극대화된 금속 촉매 효과는 $1 \mathrm{ppm}$ 의 $\mathrm{Cl}_{2}$ 가스 감 응 평가 결과, 상온에서 $33.8 \%$ 의 감도와 $65 \mathrm{ppb}$ 의 최소 검출 한계 농도를 보임으로써 확인이 되었다. 이 방법은 기존의 진공 증착법이 가지는 단면 증착의 단점을 극복하 면서 용액법에서 사용되는 기타 환원제 첨가없이 비교적 간단한 방법으로 짧은 시간에 감응 재료 표면 전체를 고 르게 금속 촉매로 기능화할 수 있는 장점이 새롭다.

위 결과들은 금속 촉매를 탄소소재 기반 감응 재료에 적용하여 감응 특성을 향상시킨 연구들로 최근에는 더 나아가 촉매 물질의 균일성, 분산성, 크기/형상 제어 등 
CERAMIST

특 집 미치선우

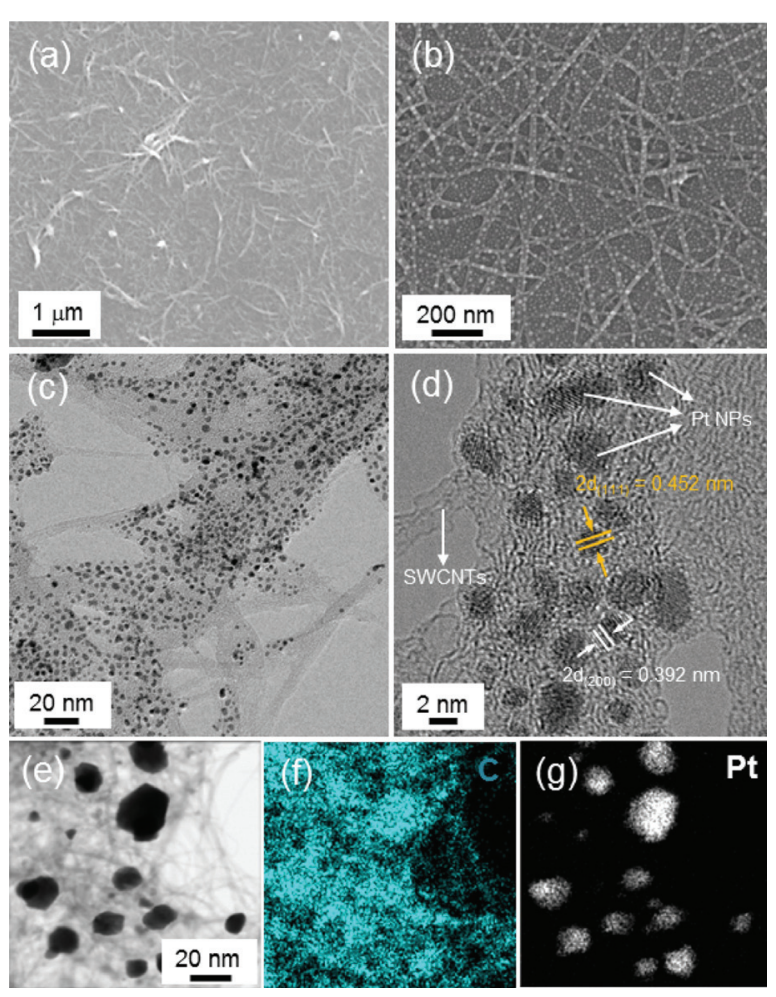

Fig. 2. 촉매형 Pt 나노입자가 기능화된 SWCNTs 기반 감응 재료 ${ }^{30)}$.

을 통한 금속 촉매 효과 극대화를 위한 연구들이 다수 진 행되고 있다. 금속 촉매 물질을 상용 센서에 적용하기 위
해서는 최적화된 금속 촉매 물질 공정기술 확보가 중요 하다.

\section{3 산화물 입자-탄소소재 복합체 기반 상온 동작 가스센서}

일반적으로, 촉매 물질의 역할은 크게 두 가지로 분류 할 수 있는데 $\mathrm{Au}, \mathrm{Pt}, \mathrm{Ag}$ 등과 같은 귀금속 물질을 촉매 로써 활용하게 되면 spillover 효과31)를 통해 표면에서 감 응 반응에 참여할 수 있는 가스 분자들의 전체 농도를 증 가시키는 중요한 화학적(chemical sensitization) 역할 이 있고, 촉매 물질과 감응 재료의 일함수(work function) 차이 또는 이종 접합으로 인한 전자 천이에 따 른 추가적인 전자공핍층 형성을 야기하여 감응 특성에 영 향을 미치는 전자적 증감(electronic sensitization) 역할 이 있다 ${ }^{32,33)}$.

Chen 등 ${ }^{34)}$ 은 응집되어 있지 않은 $\mathrm{n}$-형의 $\mathrm{SnO}_{2}$ 나노 결정과 $\mathrm{p}$-형의 $\mathrm{CNT}$ 계면 사이에서 발생하는 전자 천이 가 상온에서의 감응 특성에 미치는 영향에 대해 평가했다 (Fig. 3 and Fig. 4). 다중벽 CNT(MWCNT) 표면에 아 크 플라즈마 방전을 이용하여 에어로졸 상태의 $\mathrm{SnO}_{2}$ 나 노 결정을 성공적으로 $\mathrm{MWCNT}$ 표면에 기능화하였고, 상온에서 $\mathrm{NO}_{2}, \mathrm{H}_{2}$, 그리고 $\mathrm{CO}$ 가스에 대한 감응 평가를

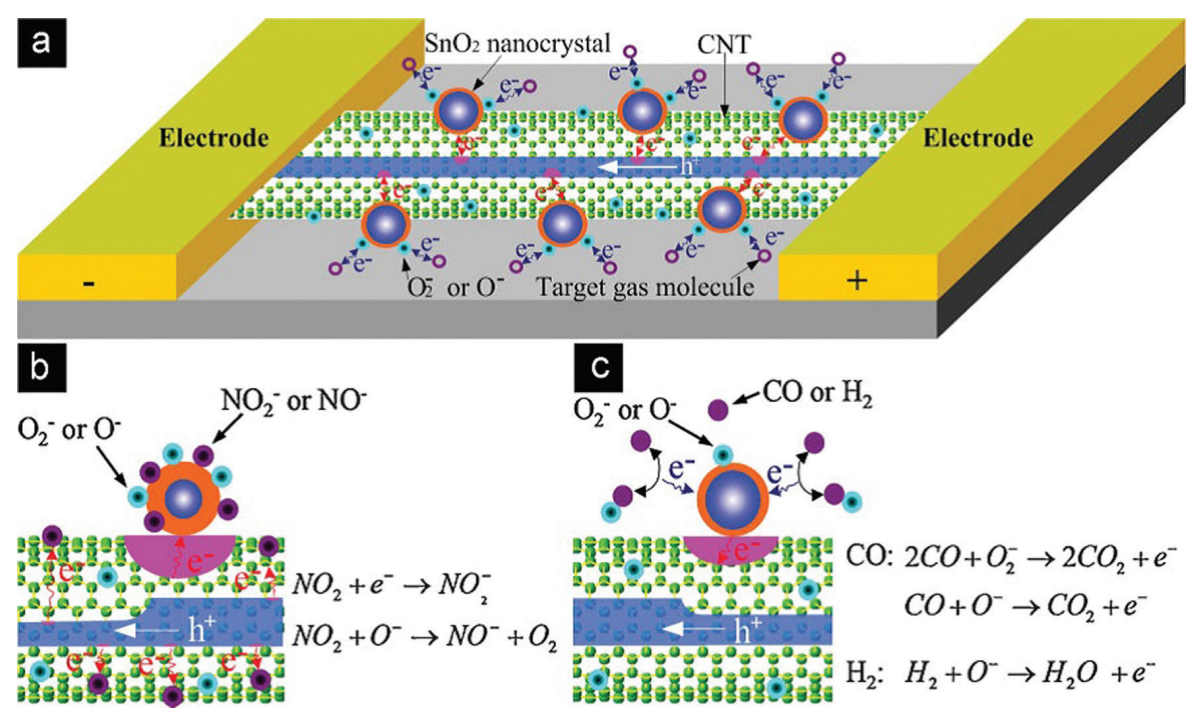

Fig. 3. $\mathrm{SnO}_{2}-\mathrm{MWCNT}$ 감응 재료의 가스 감응 기구 ${ }^{34)}$. 


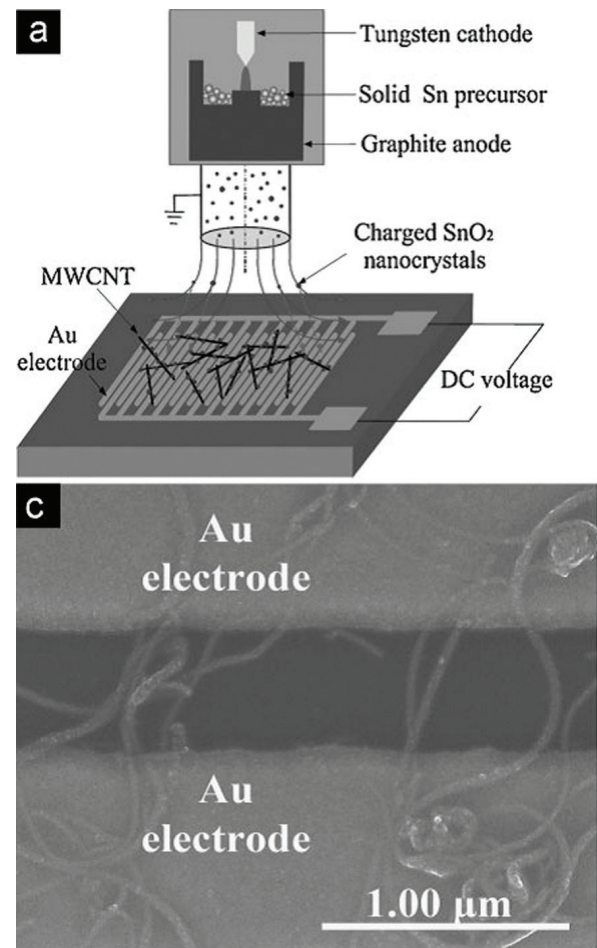

Fig. 4. $\mathrm{SnO}_{2}$ 나노 입자가 기능화된 MWCNT 기반 감응 재료 ${ }^{34}$.

실시했다. 합성된 감응 재료를 이용하여 상온에서 1000 $\mathrm{ppm}$ 의 $\mathrm{H}_{2}, 100 \mathrm{ppm}$ 의 $\mathrm{CO}, 100 \mathrm{ppm}$ 의 $\mathrm{NO}_{2}$ 건조혼합 가스 감응 평가를 실시한 결과, $\mathrm{NO}_{2}$ 가스에 높은 감응 특 성과 장기 안정성을 나타내었다. Chen 등은 $\mathrm{SnO}_{2}$ 와 $\mathrm{CNT}$ 사이의 계면에서 발생한 전자 천이에 의한 감응 재 료 내의 전도층 두께 변화가 $\mathrm{NO}_{2}$ 감응 특성 향상에 기여 하였다고 해석하였다.

$\mathrm{Lu}$ 등 35$)$ 은 수열합성법과 동결건조법을 이용하여 다공 성 $\mathrm{Co}_{3} \mathrm{O}_{4}$ 를 합성한 후 화학적 환원 처리를 거쳐 $\mathrm{Co}_{3} \mathrm{O}_{4}-$ $\mathrm{RGO}$ 복합체를 합성했다(Fig. 5). 순수한 다공성 $\mathrm{Co}_{3} \mathrm{O}_{4}$ 나노구조체와 비교를 위해 합성된 복합체의 감응 특성을 총 12 종의 가스에 대해 평가하였고, $\mathrm{NO}_{2} 5 \mathrm{ppm}$ 에 대하 여 순수한 다공성 $\mathrm{Co}_{3} \mathrm{O}_{4}$ 대비 약 2.3배 향상된 감응 특성 을 상온에서 보였다. 특히, 합성된 $\mathrm{Co}_{3} \mathrm{O}_{4}-\mathrm{RGO}$ 복합체 는 대표적 환원성 가스인 휘발성 유기화합물(Volatile Organic Compounds, VOCs)에 대해서는 전혀 반응을 하지 않았지만, 순수한 $\mathrm{CO}_{3} \mathrm{O}_{4}$ 다공체는 VOCs에 대해서 높은 감응성을 나타내었다. 이 결과는 산화물 $\mathrm{Co}_{3} \mathrm{O}_{4}$ 와
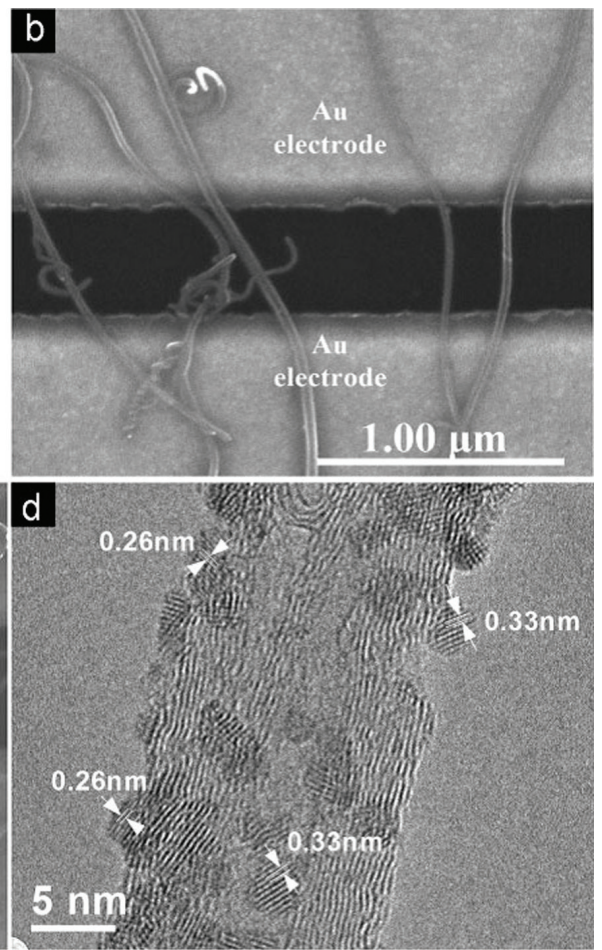

$\mathrm{RGO}$ 사이의 일함수 차이에 따른 전하 이동으로 인해 $\mathrm{Co}_{3} \mathrm{O}_{4}$ 표면과 반응 가스의 활성화 에너지 크기 변화에 기 인한다고 보고하였다.

Wongchoosuk 등 36$)$ 은 화학기상증착법을 이용하여 3 차원(3D) 구조의 그래핀-CNT를 합성한 후 스파크로 열 처리하여 $\mathrm{TiO}_{2}$ 나노 입자가 기능화된 $3 \mathrm{D}$ 그래핀-CNT 나노구조물 센서를 구현했다. 제작된 $3 \mathrm{D}$ 나노구조물은 상온에서 톨루엔 $500 \mathrm{ppm}$ 가스에 대한 감응 특성 측정 결과 $42.9 \%$ 의 감도를 보였고, 이는 $3 \mathrm{D}$ 그래핀-CNT 나 노구조물과 비교했을 때 약 7 배 증가된 수치이다. 또한 반응 및 회복속도가 약 2 초 정도로 매우 빠른 반응/회복 속도를 보였다. 이 결과는 앞서 기술한 Chen 등과 Lu 등 이 제작한 감응 재료 시스템(산화물-탄소소재 복합체)과 유사하지만 전혀 다른 감응 결과(환원성 가스인 톨루엔 검지능 향상)를 나타냈다. 따라서, 산화물-탄소소재 복 합체 나노구조물 센서 설계시 감응 재료 선정과 감응 재 료의 전자적 증감을 야기할 수 있는 촉매 선정이 반드시 고려되어야 하는 중요한 인자임을 보여주는 결과이다. 


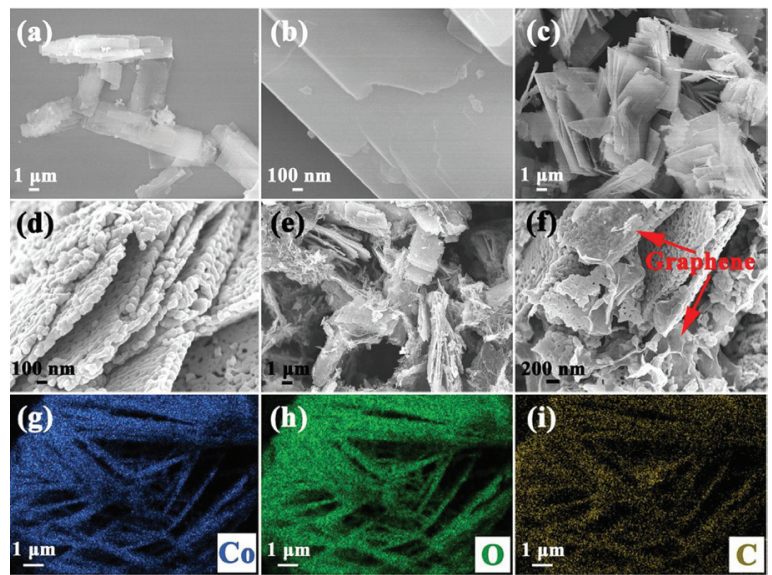

Fig. 5. 다공성 $\mathrm{Co}_{3} \mathrm{O}_{4}$ 나노 slices가 기능화된 RGO 기반 감응 재료 ${ }^{35)}$.

\section{4 결함(Defect)이 유발된 탄소소재 기반 상온 동작 가스센서}

탄소 나노재료 내의 여러 결함은 가스 감응에 있어서 중요한 역할을 하는 것으로 알려져 있다 ${ }^{37)}$. 특히 탄소소 재 표면에 존재할 수 있는 탄소 원자 빈자리 혹은 edge 부분에 존재하는 여러 작용기(수산화기 등)는 가스 분자 의 흡착과 확산을 용이하게 할 수 있기 때문이다. 따라서 고의적으로 탄소소재 표면에 결함들을 생성시켜 가스 감 응 특성을 향상시키는 연구가 많이 진행되었고, 이를 이
용한 가스 센서의 연구도 활발하다.

Masel 등 ${ }^{38)}$ 은 그래핀 내의 결함이 가스 감응 특성에 미 치는 효과를 확인하기 위해 순수한 그래핀과 주름을 가진 다결정 그래핀을 센서 소자로 제작하여 가스 감응 특성을 평가하였다. 아주 소수의 점결함을 가지고 있는 순수한 그래핀의 경우 유기화합물 가스인 1,2-dichlorobenzene 과 톨루엔에 대해 거의 반응하지 않았지만, 선결함을 다 수 포함한 다결정 그래핀의 경우 해당 가스에 대한 감응 도가 상당히 증가하는 것을 확인하였다. 이는 주름을 가 진 다결정 그래핀의 경우, 선결함 주위에서 전하 전도가 감소되고 그 결과 그래핀 전체 전도도 변화로 나타난다고 해석했다. Masel 등은 그들의 주장을 뒷받침하기 위한 실험으로 선결함이 존재하는 다결정 그래핀 시트를 약 $2 \sim 5 \mu \mathrm{m}$ 너비를 가진 마이크로 리본 형태로 패턴 후 감 응 특성을 측정하였다. 그 결과 마이크로 리본 형태로 패 턴된 그래핀의 가스 감응 특성은 눈에 띄게 향상되었고, 특히 1,2-dichlorobenzene에 대한 감응 특성은 약 2 배 정도 향상되는 결과를 보였다.

Chen 등 39$)$ 은 그래핀 산화물(GO, Graphene Oxide)을 수열 처리하여 구멍이 딿린 RGO 시트를 합성했다(Fig. 6). RGO 시트 표면상의 수 많은 구멍들은 수열 처리 중 발생하는 증기와의 가스화(gasification) 반응에 의해 생
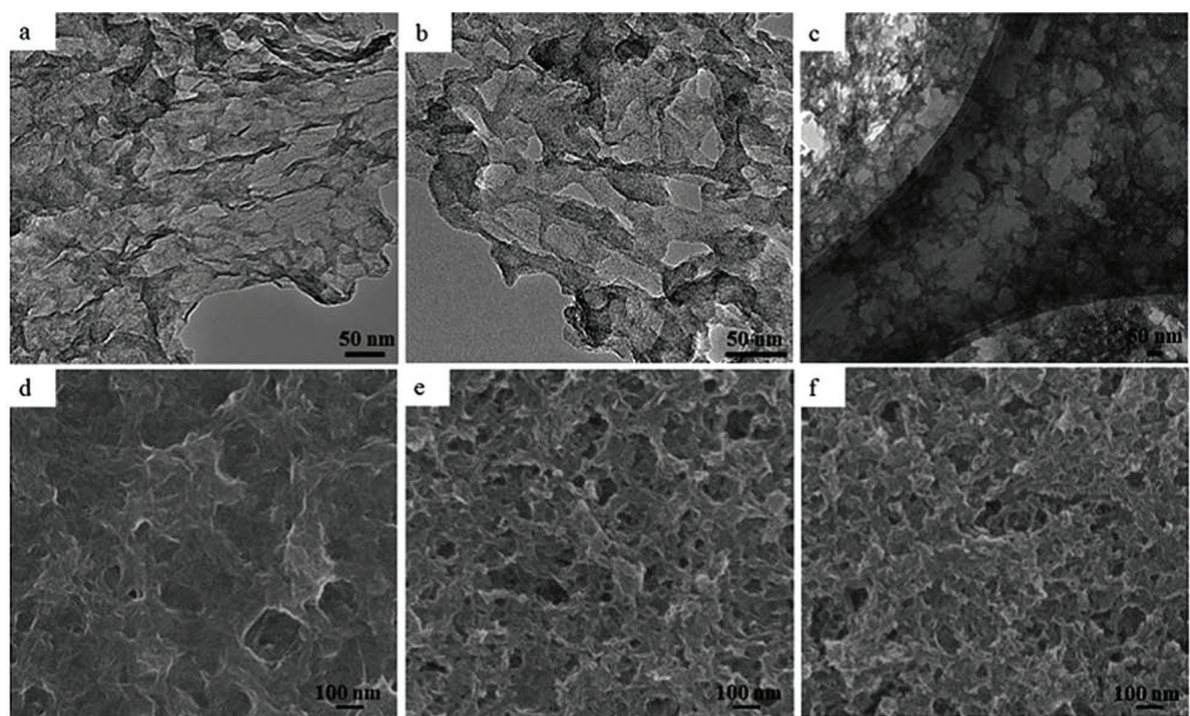

Fig. 6. 수열합성에 의해 결함이 생성된 RGO 감응 재료 ${ }^{39}$ 
성되었고, 의도적으로 뚫려진 구멍과 가스 감응의 상관관 계를 파악하기 위해 산화성 $\mathrm{NO}_{2}$ 가스와 환원성 $\mathrm{NH}_{3}$, $\mathrm{CO}, \mathrm{H}_{2} \mathrm{~S}$, 그리고 $\mathrm{H}_{2}$ 가스들에 대한 감응 특성을 평가하 였다. 상온에서 $3 \mathrm{ppm} \mathrm{NO}$ 가스에 대해 $31.8 \%$ 의 감응 도를 나타냈고, 이 결과는 기존의 보고된 RGO 감응 재료 대비 월등히 향상된 수치임을 보였다. 또한 합성된 구멍 이 뚫린 $\mathrm{RGO}$ 시트는 $\mathrm{ppb}$ 수준의 $\mathrm{NO}_{2}$ 가스도 검출이 가 능하였다. 이는 탄소소재의 표면에 의도적으로 형성한 결 함(구멍)이 가스 감응 특성 향상에 효과적으로 이용될 수 있음을 보여준다.

Jang 등 40)은 RGO 감응 재료가 필연적으로 가지는 느 린 센서 신호의 반응속도 그리고 순수한 공기로 분위기가 바뀌었을 때의 비가역적인 회복 거동을 대체하기 위한 감 응 재료로 $\mathrm{GO}$ 감응 재료를 제안하였다. 1 윈리 계산 (First-principles calculation)을 통해 해석된 실험 결 과들은 $\mathrm{NO}_{2}$ 분자 흡착과 탈착시 $\mathrm{GO}$ 표면의 수산화 작용 기의 회전 운동이 빠르고 가역적인 $\mathrm{NO}_{2}$ 감응 거동을 가 능하게 하는 것을 규명하였다.

한편 Byun 등 41)은 단순한 열처리 공정을 통해 고의적 으로 SWCNT의 표면에 결함을 형성한 후 가스 감응 특 성을 평가하였다. 열처리 공정 동안 발생할 수 있는 산화 작용을 최소화하기 위해 고속열처리(RTA, Rapid
Thermal Annealing)장치를 사용하여 1분 동안 아르곤 분위기에서 실시하였으며, 다양한 온도 범위(300 $800^{\circ} \mathrm{C}$ )에서 열처리를 하였다. 최적 열처리 조건에서 열 처리된 결함이 유도된 SWCNT 감응 재료의 $\mathrm{NO}_{2}$ 가스 2 $\mathrm{ppm}$ 에 대한 감응도는 순수한 SWCNT 감응와 비교해서 약 2 배 정도 향상되는 것을 확인하였다.

\section{5 촉매 입자/결함-탄소소재 복합체 기반 상온 동작 가스센서}

앞서 탄소소재 기반 가스센서의 감응도 향상을 위한 여 러가지 방법들을 소개하였다. 본 절에서는 탄소소재 기반 감응 재료에 금속/산화물 촉매 물질과 결함이 결합되어 발현된 동반 상승효과가 가스 감응 특성에 미치는 효과에 대해 소개하고자 한다.

Collins 등 42)은 단일 SWCNT 기반 가스 센서의 $\mathrm{H}_{2}$ 가 스에 대한 감응도를 극대화하기 위해 $\mathrm{Pd}$ 촉매 나노 입자 와 점(point) 결함을 동시에 SWCNT 표면에 생성시킨 연 구를 진행했다(Fig. 7). 순수한 SWCNT 기반 센서의 경 우, $\mathrm{H}_{2}$ 가스에 대해 전혀 반응을 하지 않았지만, $\mathrm{Pd}$ 나노 입자를 촉매 물질로 SWCNT 표면에 기능화하게 되면 감 응 신호는 작지만 $\mathrm{H}_{2}$ 가스에 감응을 하는 것을 확인했다. $\mathrm{Pd}$ 촉매 입자를 기능화하여 얻은 미미한 $\mathrm{H}_{2}$ 감응 신호를
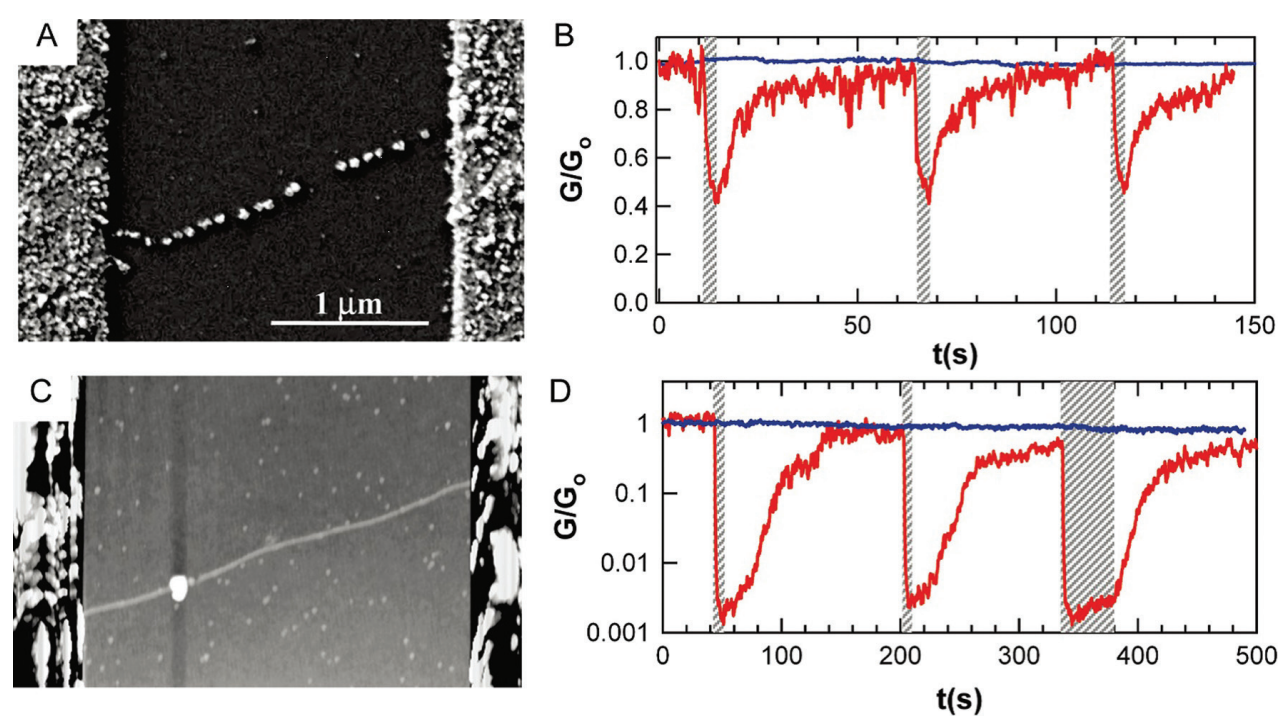

Fig. 7. Pd/결함-SWCNT 기반 감응 재료의 수소 감응 특성 42 . 
극대화하기 위해 Collins 등은 결함을 $\mathrm{Pd}$ 나노 입자가 기 능화된 SWCNT 표면에 도입한 $\mathrm{Pd}$ 나노입자/결 함-SWCNT 센서를 제작하여 $\mathrm{H}_{2}$ 감응 특성을 평가 후 비 교하였다. 그 결과 제작된 $\mathrm{Pd}$ 나노입자/결함-SWCNT 센서의 $\mathrm{H}_{2}$ 감응도는 결함없이 $\mathrm{Pd}$ 나노입자가 기능화된 $\mathrm{SWCNT}$ 의 $\mathrm{H}_{2}$ 감응도에 비해 약 30 배 정도 향상된 감응 특성을 보이는 것을 확인했다. 이 결과는 탄소 기반의 감 응 재료에 촉매 물질과 결함을 적절히 조합하게 되면 특 정 가스에 대한 감응 특성을 획기적으로 향상시킬 수 있 는 좋은 예가 될 수 있다.

또한 본 연구진은 마이크로파를 조사하는 동안 발생하 는 줄 열(Joule Heating) ${ }^{43)}$ 을 이용하여 SWCNTs 표면 에 결함을 생성함과 동시에 산화물 나노 입자를 기능화 하기 위해 혼합 분말(SWCNTs와 산화물 전구체) 시료 에 마이크로파를 최적화된 조건에서 직접 조사한 후 다 양한 시스템의 감응 재료를 합성하였다. 이와 같이 합성 된 감응 재료 중 $\mathrm{SnO}_{2}$ 나노입자/결함-SWCNTs 복합체 는 $1 \mathrm{ppm}$ 의 에탄올 가스에 대해 뛰어난 감응 특성을 보 였다. 순수한 SWCNT 기반의 감응 재료는 고농도의 에 탄올 가스에 노출이 되어도 반응을 하지 않았지만, 마이 크로파 조사를 통한 결함 형성 후 에탄올 가스에 반응을 보였다. 특히 $\mathrm{SnO}_{2}$ 나노 입자가 동시에 기능화된 감응 재료의 경우 결함이 기능화된 SWCNTs 감응 재료의 에 탄올 감응도 대비 약 2 배 이상 향상되는 것을 확인하였 다. 이 결과는 $\mathrm{SnO}_{2}$ 나노 입자의 촉매 효과와 결함에 의 한 피검 가스의 흡/탈착 및 확산의 용이성이 동시에 나 타냄을 잘 보여준다.

이상과 같이 상온 동작하는 반도체 탄소 나노재료 기반 감응 재료의 상온에서의 낮은 감응도와 느린 반응속도를 극복하기 위한 여러 방안에 대해 소개하였다. 촉매 물질 과 결함으로 표면이 기능화된 탄소 나노재료는 피검가스 가 감응 재료 전체에 빠르게 확산될 수 있기 때문에 향상 된 가스 감응도와 빠른 반응 및 회복 속도를 가진 가스 센 서 설계에 매우 유리하다. 이는 유해화학가스의 실시간 감지가 가능하고 전자 코(e-nose), 전자 혀(e-tongue) 등 인공 감응 감각에 효과적으로 적용될 수 있을 것으로 기대된다.

\section{3. 결론}

탄소 소재를 기반으로 한 나노 재료를 활용하여 가스 센서 분야에 적용하는 것은 소형화 및 집적화가 가능하 며, 상온에서 동작하기 때문에 저전력 구동에 유리하고, 비교적 간단한 공정으로 구현할 수 있어 매우 효율적이면 실용적인 기술로 연구되고 있다. 또한 저차원 구조의 탄 소 나노 소재를 표면 기능화 구조, 복합체 구조, 이종 접 합 구조 등 다양한 구조로 제조하게 되면 향상된 감응 특 성을 가지는 가스 센서로 개발이 가능할 뿐만 아니라 특 정 가스를 선택적으로 검출할 수 있는 가스 센서로의 개 발도 가능하다. 최근에는 사물 인터넷(IoT, Internet of Things)의 발전으로 사람이 지니고 다니는 디바이스에 가스 센서를 접목시켜 실시간으로 모니터링이 가능하도 록 하기 위해 착용이 가능한(wearable) 소자 혹은 유연 (flexible) 소자 개발에 대한 연구가 활발히 진행되고 있 다. 따라서 탄소 나노 소재가 가지는 여러 유리한 물성은 이러한 소자에 적용이 유리하여 많은 연구 그룹에서 개발 연구에 집중하고 있다. 특히, 사람의 호기(날숨)에 포함 된 휘발성 유기화합물을 선택적으로 검출하여 사람의 질 병 유무를 진단할 수 있는 의료 분야와 친환경 에너지에 대한 관심 증대와 화석연료 고갈에 따른 수소 관련 산업 의 확대에 따른 수소 가스 센서에 대한 탄소 소재 기반의 가스 센서의 적용이 매우 유망하다.

\section{참고문헌}

1. T. Seiyama, A. Kato, K. Fujishi, and M. Nagatani, "A New Detector for Gaseous Components Using Semiconductive Thin Films," Anal. Chem., 34 [11] 1502-3 (1962)

2. A. Mirzaei, J.-H. Kim, H. W. Kim, and S. S. Kim, "Resistive-Based Gas Sensors for Detection of Benzene, Toluene and Xylene (BTX) Gases: A Review," J. Mater. Chem, C, 6 4342-70 (2018)

3. M.-H. Kim, J.-S. Jang, W.-T. Koo, S.-J. Choi, S.-J. Kim, D. -H. Kim, and I.-D. Kim, "Bimodally Porous $\mathrm{WO}_{3}$ Microbelts Functionalized with $\mathrm{Pt}$ Catalysts for Selective $\mathrm{H}_{2} \mathrm{~S}$ Sensors," ACS Appl. Mater. Interfaces, 10 20643-51 (2018)

4. S. -W. Choi, A. Katoch, J.-H. Kim, and S. S. Kim, 
"Remarkable Improvement of Gas-Sensing Abilities in p-type Oxide Nanowires by Local Modification of the Hole-Accumulation Layer," ACS Appl. Mater. Interfaces, 7 647-57 (2015)

5. H. W. Kim, H. G. Na, Y. J. Kwon, S. Y. Kang, M. S. Choi, J. H. Bang, P. Wu, and S. S. Kim, "MicrowaveAssistedSynthesisof Graphene- $\mathrm{SnO}_{2}$ Nanocomposites and Their Applications in Gas Sensors," ACS Appl. Mater. Interfaces, 9 31667-82 (2017)

6. J. Kong, N. R. Franklin, C. Zhou, M. G. Chapline, S. Peng, K. Cho, and H. Dai, "Nanotube Molecular Wires as Chemical Sensors," Science, 287 622-5 (2000)

7. L. Valentini, I. Armentano, J. M. Kenny, C. Cantalini, L. Lozzi, and S. Santucci, "Sensors for Sub-ppm $\mathrm{NO}_{2}$ Gas Detection Based on Carbon Nanotube Thin Films," Appl. Phys. Lett., 82 [6] 961-3 (2003)

8. C. Cantalini, L. Valentini, L. Lozzi, I. Armentano, J. M. Kenny, and S. Santucci, " $\mathrm{NO}_{2}$ Gas Sensitivity of Carbon Nanotubes Obtained by Plasma Enhanced Chemical Vapor Deposition," Sens. Actuators B: Chem., 93 333-7 (2003)

9. K. H. An, S. Y. Jeong, H. R. Hwang, and Y. H. Lee, "Enhanced Sensitivity of a Gas Sensor Incorporating Single-Walled Carbon Nanotube-Polypyrrole Nanocomposites," Adv. Mater., 16 [12] 1005-9 (2004)

10. Z. J. Han, H. Mehdipour, X. G. Li, J. Shen, L. Randeniya, and H. Y. Yang, "SWCNT Networks on Nanoporous Silica Catalyst Support: Morphological and Connectivity Control for nanoelectronic, GasSensing, and Biosensing Devices, ACS Nano, 6 580919 (2012)

11. M. Y. Lone, A. Kumar, S. Husain, M. Zulfequar, Harsh, and M. Husain, "Growth of Single Wall Carbon Nanotubes using PECVD Technique: An Efficient Chemiresistor Gas Sensor," Physica E, 87 261-5 (2017)

12. D. Kumar, I. Kumar, P. Chaturvedi, A. Chouksey, R. P. Tandon, and P. K. Chaudhury, "Study of Simultaneous Reversible and Irreversible Adsorption on Single-Walled Carbon Nanotube Gas Sensor," Mater. Chem. Phys., 177 276-82 (2016)

13. P. Slobodian, P. Riha, A. Lengalova, P. Svoboda, and P. Saha, "Multi-Wall Carbon Nanotube Networks as Potential Resistive Gas Sensors for Organic Vapor Detection," Carbon, 49 2499-507 (2011)

14. H. J. Yoon, D. H. Jun, J. H. Yang, Z. X. Zhou, S. S. Yang, and M. M.C. Cheng, "Carbon Dioxide Gas Sensor Using a Graphene Sheet," Sens. Actuators B:
Chem., 157 310-3 (2011)

15. G. H. Lu, L. E. Ocola, and J. H. Chen, "Reduced Graphene Oxide for Room-Temperature Gas Sensors," Nanotechnology, 20445502 (2009)

16. J. Wang, Y. Kwak, I. Y. Lee, S. Maeng, and G. H. Kim, "Highly Responsive Hydrogen Gas Sensing by Partially Reduced Graphite Oxide Thin Films at Room Temperature," Carbon, 50 4061-7 (2012)

17. R. Kumar, K. K. Avasthi, and A. Kaur, "Fabrication of Chemiresistive Gas Sensors based on Multistep Reduced Graphene Oxide for Low Parts per Million Monitoring of Sulfur Dioxide at Room Temperature," Sens. Actuators B: Chem., 242 461-8 (2017)

18. Y. Seekaew, D. Phokharatkul, A. Wisitsoraat, and C. Wongchoosuk, "Highly Sensitive and Selective RoomTemperature $\mathrm{NO}_{2}$ Gas Sensor Based on Bilayer Transferred Chemical Vapor Deposited Graphene," Appl. Surf. Sci., 404 357-63 (2017)

19. S. Ju, J. M. Lee, Y. Jung, E. Lee, W. Lee, and S. J. Kim, "Highly Sensitive Hydrogen Gas Sensors Using Single-Walled Carbon Nanotubes Grafted with Pd Nanoparticles," Sens. Actuators B: Chem., 146 122-8 (2010)

20. K. H. Lee, V. Scardaci, H. Y. Kim, T. Hallam, H. Nolan, and B. E. Bolf, "Highly Sensitive, Transparent, and Flexible Gas Sensors Based on Gold Nanoparticle decorated Carbon Nanotubes," Sens. Actuators B: Chem., 188 571-5 (2013)

21. S. Mao, S. M. Cui, K. H. Yu, Z. H. Wen, G. H. Lu, and J. H. Chen, "Ultrafast Hydrogen Sensing through Hybrids of Semiconducting Single-Walled Carbon Nanotubes and Tin Oxide Nanocrystals," Nanoscale, 4 1275-9 (2012)

22. A. Sharma, M. Tomar, and V. Gupta, "Room Temperature Trace Level Detection of $\mathrm{NO}_{2}$ Gas Using $\mathrm{SnO}_{2}$ Modified Carbon Nanotubes Based sensor," J. Mater. Chem., 22 23608-16 (2012)

23. D. Z. Zhang. Y. E. Sun, and Y. Zhang, "Fabrication and Characterization of Layer-by-Layer Nano SelfAssembled ZnO Nanorods/Carbon Nanotube Film for Ethanol Gas Sensing Application at Room Temperature," J. Mater. Sci., 26 7445-51 (2015)

24. G. P. Evans, M. J. Powell, I. D. Johnson, D. P. Howard, D. Bauer, andJ. A. Darr, "Room Temperature Vanadium Dioxide-Carbon Nanotube Gas Sensors Made via Continuous Hydrothermal Flow Synthesis," Sens. Actuators B: Chem., 255 1119-29 (2018)

25. J. L. Johnson. A. Behnam, S. J. Pearton, and A. 


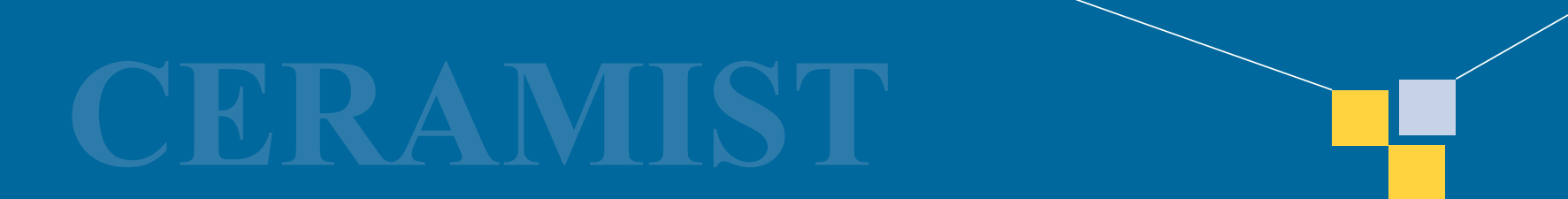

Ural, "Hydrogen Sensing Using Pd-Functionalized Multi-Layer Graphene Nanoribbon Networks" $A d v$. Mater., 22 4877-80 (2010)

26. R. Kumar, d. Varandani, B. R. Mehta, V. N. Singh, Z. H. Wen, and X. I. Feng, "Fast Response and Recovery of HydrogenSensinginPd-PtNanoparticleGraphene Composite Layer," Nanotechnology, 22 275719 (2011)

27. A. Esfandiar, A. Irajizad, O. Akhavan, S. Ghasemi, and M. R. Gholami, "Pd- $\mathrm{WO}_{3} /$ Reduced Graphene Oxide Hierarchical Nanostructures as Efficient Hydrogen Gas Sensors," Int. J. Hydrogen Energy, 39 8169-79 (2014)

28. Z. M. Ao, J. Yang, S. Li, and Q. Jiang, "Enhancement of CO Detection in Al doped Graphene," Chem. Phys. Lett., 461 276-9 (2008)

29. L. Huang, Z. Wang, J. Zhang, J. Pu, Y. Lin, S. Xu, L. Shen, Q. Chen, and W. Shi, "Fully Printed, RapidResponse Sensors Based on Chemically Modified Graphene for Detecting $\mathrm{NO}_{2}$ at Room Temperature," ACS Appl. Mater. Interfaces, 6 7426-33 (2014)

30. S.-W. Choi, B. -M. Kim, S.-H. Oh, and Y. T. Byun, "Selective Detection of Chlorine at Room Temperature Utilizing Single-Walled Carbon Nanotubes Functionalized with Platinum Nanoparticles Synthesized via Ultraviolet Irradiation," Sens. Actuators B: Chem., 243 414-22 (2017)

31. A. Kolmakov, D. O. Klenov, Y. Lilach, S. Stemmer, and M. Moskovits, "Enhanced Gas Sensing by Individual $\mathrm{SnO}_{2}$ Nanowires and Nanobelts Functionalized with Pd Catalyst Particles," Nano Lett., 5 [4] 667-73 (2005)

32. Y.-M. Jo, C.-S. Lee, R. Wang, J.-S. Park, and J.-H. Lee, "Highly Sensitive and Selective Ethanol Sensors Using Magnesium doped Indium Oxide Hollow Sphere," J. Korean Ceram. Soc., 54 [4] 303-7 (2017)

33. Z. U. Abideen, J. -H. Kim, J.-H. Lee, J.-Y. Kim, A. Mirzaei, H. W. Kim, and S. S. Kim, "Electrospun Metal Oxide Composite Nanofibers Gas Sensors: A Review," J. Korean Ceram. Soc., 54 [5] 366-79 (2017)

34. G. Lu, L. E. Ocola, and J. Chen, "Room-Temperature Gas Sensing Based on Electron Transfer between Discrete Tin Oxide Nanocrystals and Multiwalled Carbon Nanotubes," Adv. Mater., 21 2487-91 (2009)

35. B. Zhang, M. Cheng, G. Liu, Y. Gao, L. Zhao, S. Li, Y. Wang, F. Liu, X. Liang, T. Zhang, and G. Lu, "Room Temperature $\mathrm{NO}_{2}$ Gas Sensor Based on Porous $\mathrm{Co}_{3} \mathrm{O}_{4}$ Slices/Reduced Graphene Oxide hybrid," Sens.
Actuators B: Chem., 263 387-99 (2018)

36. Y. Seekaew, A. Wisitsoraat, D. Phokharatkul, and C. Wongchoosuk, "Room Temperature Toluene Gas Sensor Based on $\mathrm{TiO}_{2}$ Nanoparticles Decorated 3D Graphene-Carbon Nanotube Nanostructures," Sens. Actuators B: Chem., 279 69-78 (2019)

37. J. H. Lehman, M. Terrones, E. Mansfield, K. E. Hurst, V. Meunier, "Evaluating the Characteristics of Multiwall Carbon Nanotubes," Carbon, 49 2581-602 (2011)

38. A. Salehi-Khojin, D. Estrada, K. Y. Lin, M.-H. Bae, F. Xiong, E. Pop, and R. I. Masel, "Polycrystalline Graphene Ribbons as Chemiresistors," Adv. Mater., $2453-57$ (2012)

39. D. H. Wang, Y. Hu, J. J. Zhao, L. L Zeng, X. M. Tao, and W. Chen, "Holey Reduced Graphene Oxide Nanosheets for High Performance Room Temperature Gas Sensing," J. Mater. Chem. A, 2 17415-20 (2014)

40. Y. R. Choi, Y.-G. Yoon, K. S. Choi, J. H. Kang, Y. -S. Shim, Y. H. Kim, H. J. Chang, J.-H. Lee, C. R. Park, S. Y. Kim, and H. W. Jang, "Role of Oxygen Functional Groups in Graphene Oxide for Reversible Room-Temperature $\mathrm{NO}_{2}$ Sensing," Carbon, 91 17887 (2015)

41. J. Kim, S.-W. Choi, J.-H. Lee, Y. Chung, and Y. T. Byun, "Gas Sensing Properties of Defect-Induced Single-Walled Carbon Nanotubes," Sens. Actuators B: Chem., 228 688-92 (2016)

42. V. R. Khalap, T. Sheps, A. A. Kane, and P. G. Collins, "Hydrogen Sensing and Sensitivity of PalladiumDecorated Single-Walled Carbon Nanotubes with Defects," Nano Lett., 10 896-901 (2010)

43. Y. Byoun, S. Park, C. Jin, Y.-J. Song, and S.-W. Choi, "Highly Sensitive and Selective Ethanol Detection at Room Temperature Utilizing Holey SWCNT-Sn/ $\mathrm{SnO}_{2}$ Nanocomposites Synthesized by Microwave Irradiation,” Sens. Actuators B: Chem., In press.

\section{○○ 최선 우}

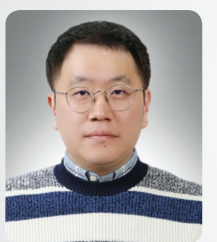

○ 2014년 인하대학교 신소재공학과 박사

○ 2014년 인하대학교 박사후연구원

( 2014년 한양대학교 박사후연구원

ㅇ 2015-2017년 한국과학기술연구원 박사후연구원

○ 2017-현재 강원대학교 신소재공학과 조교수 